\title{
EFL Lecturers' Perception on the Use of Lesson Study in Improving Pedagogical Content Knowledge
}

\author{
Intan Septia Latifa
}

Universitas Pendidikan Indonesia (UPI), Bandung, Indonesia

\section{Abstract}

Lesson Study (LS) assists teachers and lecturers to improve their professionalism within the idea of collaborative work through collegiality. Not all lecturers have enough competencies dealing with pedagogical content knowledge. Nevertheless, some of them seem to be reluctant to get involved in the program. This study aims to explore lecturers' perception on the use of LS process in improving pedagogical content knowledge. It employs a qualitative method by applying descriptive study as its framework. Three EFL lecturers who teach at one of the state universities in Bandung who previously experienced LS process were being respondents in the study. The

Corresponding Author: Intan Septia Latifa intanlatifa@upi.edu

Received: 1 July 2019

Accepted: 18 July 2019

Published: 31 July 2019

Publishing services provided by Knowledge

(c) Intan Septia Latifa. This article is distributed under the terms of the Creative Commons

Attribution License, which permits unrestricted use and redistribution provided that the original author and source are credited.

Selection and Peer-review unde the responsibility of the AICLL 2019 Conference Committee.

\section{G OPEN ACCESS} data were obtained from open-ended and close-ended questionnaire focusing on two themes, the steps and processes of the LS cycle and its effectiveness in improving pedagogical skill in teaching EFL. The result of the study revealed that the lecturers had a positive perception on using LS in improving pedagogical content knowledge in teaching EFL. However, time management of conducting the discussion still became the main problem in the program. The findings above suggest that the lecturers should have more desire and enthusiasm in conducting LS in order to promote their teaching and to help them get the characteristics of effective professional developments in their work.

Keywords: EFL lecturers, lesson study, pedagogical content knowledge

\section{Introduction}

Nowadays, the importance of professional development for English teachers is extremely undeniable. Professional development is seeing as a driving force to improve the quality of teaching and learning as well as student achievement. According to Stingler and Hibert (1999), teachers are often blamed when students' performance scores are below the expectations. As the result, the teachers should take the responsibility without providing them with the tools how to handle the problems. Additionally, Seyf (1996) adds that teachers' teaching style is the main factor of the students' failure. So, focusing on teacher methodology is the most essential way to handle the students' failure. Relating this idea to professional development, the 
teachers should get adequate knowledge and skill in their teaching methodology in order to give impact to their pedagogical content knowledge which then gives impact to the students' achievement.

One idea of professional development is by engaging teachers on collaborative work through collegiality. The theoretical framework of building collegiality among teachers is social constructivism. Social constructivism emphasizes that knowledge is constructed in response to social interaction through social negotiation, discourse, reflection, and explanation. The teacher should be engaged in activities that necessitate interacting verbally and require that they communicate often with both novice and experts in their field of study (Rock \& Wilson, 2015).

Similar to the teacher, lecturer is also suggested to involve in collaborative work in order to enhance their professional development. As stated by Newmann, King and Young (2000), individual lecturer competence is the foundation to enhance classroom practice, but when it comes to improve students' achievement continuously in every academic year, lecturers are required to work collaboratively with their peers as the way to exercise their individual knowledge, skills and dispositions. However, based on some studies, lecturers only have a few chances in involving to collaborative work due to some problems, such as (1) the relationship or communication between lecturers who are less productive, which mostly influenced by their autonomy and their specialization (Tyoso, 2007); (2) the habit of the lecturers who usually work alone (Sumardi et al., 2015), so the opportunities to share knowledge with their colleagues is limited.

In addition, dealing with the idea of collaborative work above, Lesson Study (LS) can assist teachers and lecturers to build a community of practice in which teachers and lecturers routinely share resources and ideas (Lewis, Perry, \& Hurd, 2009). By working together in planning, observation, analysis and reflection on live learning, teachers and lecturers could learn from each other. They strengthen their bond and develop a habit of improving their practice by working and discussing with their colleagues (Lee \& Oyao, 2013). Sato (2014) states that collegiality is established by collaboration of design and reflection of learning in teaching practice.

Learning about the issue and relevant research reports above, this study aims to investigate EFL lecturers' perception on implementing Lesson Study in improving pedagogical content knowledge, whether they have a positive or negative perspective. Another purpose is to examine the problems encountered by the lecturers during the Lesson Study process. Based on purposes above, the research questions examined, as 
follows, (1) What is EFL lecturers' perception on using Lesson Study to improve pedagogical content knowledge?; and (2) What are the problems that lecturers encountered during Lesson Study process?.

\section{Literature Review}

\subsection{Lesson study}

Lesson Study is a method of professional development that encourages teachers to reflect on their teaching practice through a cyclical process of collaborative lesson planning, lesson observation, and examination of student learning. Initially, Lesson Study firstly has known in Japan in which it becomes the way Japanese teachers to examine student achievement. Furthermore, Stingler and Hiebert (1999) introduce Lesson Study to teachers in North America in their book about international methods of instruction. Lesson Study is now one of the fastest-growing approaches to professional development in the United States (Lewis, Perry, Hurd, \& O'Connell, 2006).

Lesson Study is also defined by Lewis (2002) as a teacher-led instructional improvement cycle in which teachers work collaboratively to complete a chain of activities. These activities can be summarized as follows: identifying objectives for student learning, preparing a research lesson, teaching/observing the lesson (one of the Lesson Study group members take a responsibility of teaching the lesson while the others observe students), revising the lesson through post-lesson discussions, interview/open-ended surveys with students and re-teaching the lesson based on the revised lesson (Stigler \& Hiebert, 1999). In short, these activities can be done in three stages, plan, do and see.

Initially, in the first stage of Lesson Study process, teachers work together to form a small group of 3-6 individuals in order to examine the objectives that their students should achieve. After that, they continue to the planning stage where the team develops a plan to investigate how students learn from the lesson. The activity begins by choosing the research theme and exploring the curriculum to find materials based on the topic being taught. After all these sources prepared, the team starts to construct the plan in the collaborative work. The teaching learning plan in Lesson Study process differs from an ordinary lesson plan because it is designed to stimulate, capture, and share the learning as well as guide the lesson (Lewis \& Hurd, 2011; Stepanek, et al., 2007).

The second stage is doing. In this stage, one member of the group is chosen as a teacher model. The teacher model will teach the lesson and other members attend the class to collect data through observation. The focus of the observation 


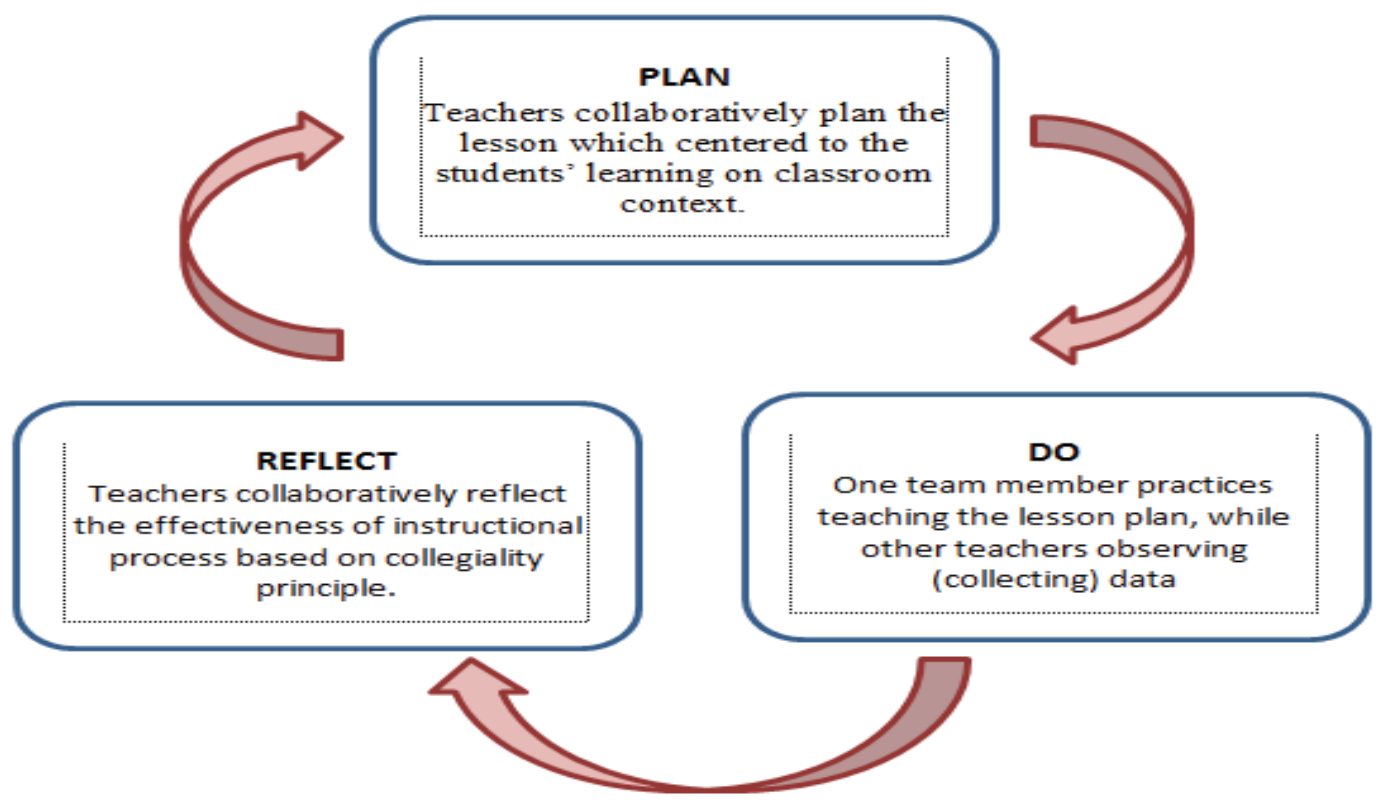

Figure 1: Stages of Lesson Study.

is on how students respond to the lesson. Observers collect rich evidence related to the learning goal during the lesson, capturing the complexity of actual teaching and learning. During the observation, observers may record detailed field notes, focus on specific types of student activity, or use checklists or rubrics to categorize or monitor student engagement, performance, thinking, and/or behavior (Lewis \& Hurd, 2011)

The final stage is seeing or reflection process, aiming to discover the advantages and disadvantages of instructional practice. In this stage, a model teacher is asked to share his/her impression during teaching practice, while the other members who act as observers requested to deliver their comments and lessons learned from instructional practice accordance to the learners' learning. All criticism and suggestions submitted wisely without degrading and hurting teachers to improvement. Based on the feedback given, the team repeats the stages from planning, doing and seeing based on the revisions in the reflection process and notice if there are any improving changes in the students' learning process.

\subsubsection{Pedagogical content knowledge}

According to Shulman (1987), Pedagogical Content Knowledge (PCK) represents the blending of content and pedagogy into an understanding of how particular topics, problems or issues are organized represented and adapted to the diverse interests and 
abilities of learners and presented for instruction. On the other hand, pedagogical content knowledge is the knowledge needed to make subject matter accessible to students. Pedagogical content knowledge can also be understood as teachers' interpretation of subject matter knowledge in the context of helping the student learning.

In relation to Lesson Study, the main feature provided by Lesson Study is to enhance teachers' professional development through a cyclical process that comprises curriculum study and formulation of goals, planning, conducting research, and reflecting on the research lessons. This leads to developing the capacity of teachers to improve teaching and increase knowledge of the lesson delivery through collaborative work among members of the team formed within Lesson Study group, where all the activities done is necessary to improve pedagogical content knowledge.

\section{Research Method}

The study employed a qualitative research design aiming at exploring and understanding the issue (Maliek \& Hamied, 2016). Moreover, this study utilized descriptive study as its framework viewing that everything is potential to provide a clue that reveals a more comprehensive understanding (Bogdan \& Biklen, 2006).

The standard used in choosing participants and sites is whether they are "information rich" (Patton cited in Creswell, 2008: 214). Based on the argument, researcher used a Purposeful sampling for this study. The participants of the study were three EFL lecturers who teach at one of state universities in Bandung, whose all of them are female. From three participants, one of them has been teaching between 6 to 10 years, while that the other two are between 3 to 5 years. All selected participant have experienced involving in the LS program during six month-period.

The data in this study was collected through a questionnaire. Initially, the questionnaire on Teachers' Perception on Implementing Lesson Study in Improving EFL Lecturers' content knowledge adopted from Wright Jr (2009), and Kanellopoulou and Darra (2018), was distributed through the link of Google form (https://docs.google. com/forms/d/e/1FAlpQLScL1p6vccKJXmLLI_IbA1qvOTIdE7vjPfOVe5wXWoUcoMbwg/ viewform?usp=sf_link) to all participants. The questionnaire consisted of 16 items of close-ended questions in which the answers to these questions, according to Likert scale, ranged from absolute disagreement to absolute agreement. Moreover, in three open-ended questions, lecturers freely expressed their views. Finally, after data collection, the data of this study analyzed through descriptive analysis. 


\section{Result and Discussion}

The result of the findings is divided based on the research questions of the study which presented below, as follows:

\section{1. $R Q$ \#1: What is EFL lecturers' perception on using Lesson Study to improve pedagogical content knowledge?}

The data related to this question were drawn from sixteen items of close-ended questionnaire. The findings acquired in this first research question consists of two main themes, teacher perceptions in relation to the steps and processes of the Lesson Study cycle and its effectiveness in improving pedagogical skill in teaching EFL. The questions of the two themes elaborate in the table below:

\section{The steps and processes of the lesson study cycle}

The finding regarding to the results of participants' responses to the lecturers' perception of the steps and processes of the Lesson Study cycle can be seen in Figure 1, as follows:

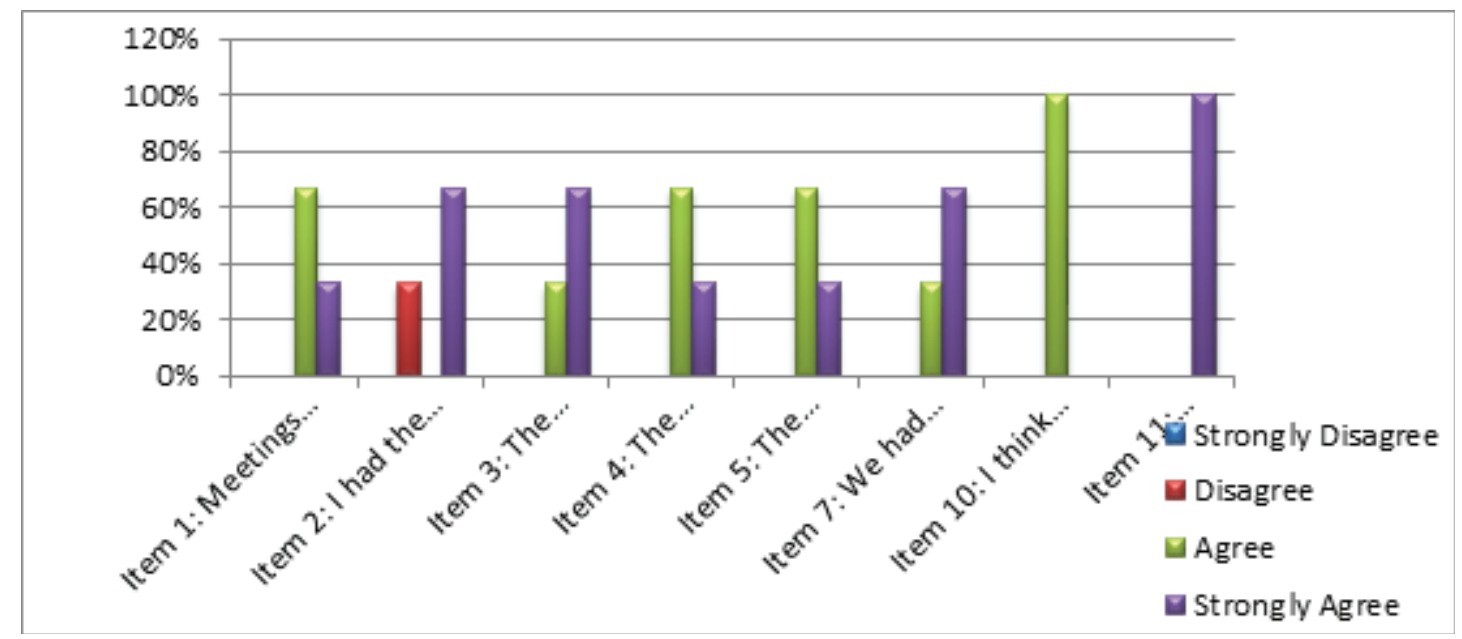

Figure 2: The lecturers' answer on the steps and processes of the Lesson Study cycle.

From the chart above, it revealed that most of lecturers had positive perspective toward the steps and processes of the Lesson Study cycle, since the answers were mostly on absolute agreement. From eight items purposed, the participants chose agree and strongly agree in five items which are item 1, item 3, item 4, item 5, and item 7. Moreover, they chose strongly agree in two other items, item 10 and item 11. Only on item 2 , there was a different view related to the time management in doing discussion, 
TABLE 1: Close-ended questions.

\begin{tabular}{|c|c|c|}
\hline Themes & $\begin{array}{l}\text { Item } \\
\text { num- } \\
\text { bers }\end{array}$ & Sample of items \\
\hline \multirow{8}{*}{$\begin{array}{l}\text { The steps and } \\
\text { processes of the } \\
\text { LS cycle }\end{array}$} & 1 & Meetings during the Lesson Study were made in a convenient time for me \\
\hline & 2 & I had the opportunity to attend all the meetings during the Lesson Study \\
\hline & 3 & $\begin{array}{l}\text { The Lesson Study team has worked effectively to plan the research } \\
\text { lesson }\end{array}$ \\
\hline & 4 & The research lesson matched our primary goal \\
\hline & 5 & $\begin{array}{l}\text { The Lesson Study team used textbooks, research, or other external } \\
\text { information to help planning the lesson }\end{array}$ \\
\hline & 7 & $\begin{array}{l}\text { We had the opportunity during the course of the Lesson Study to solve } \\
\text { problems of the research lesson in order to promote our expectations of } \\
\text { students' understanding }\end{array}$ \\
\hline & 10 & I think our research lesson was a success \\
\hline & 11 & $\begin{array}{l}\text { Observing learners' learning way of thinking during teaching or research } \\
\text { was an important learning experience }\end{array}$ \\
\hline \multirow{8}{*}{$\begin{array}{l}\text { The effectiveness } \\
\text { of LS in } \\
\text { improving } \\
\text { pedagogical skill } \\
\text { in teaching EFL }\end{array}$} & 6 & $\begin{array}{l}\text { Lecturers plan lesson more effectively than usual while participating } \\
\text { Lesson Study }\end{array}$ \\
\hline & 8 & $\begin{array}{l}\text { The development of the research lesson has allowed me to increase my } \\
\text { knowledge of teaching content }\end{array}$ \\
\hline & 9 & $\begin{array}{l}\text { The development of the research lesson allowed me to understand the } \\
\text { way students think better and / or the difficulties of my teaching content }\end{array}$ \\
\hline & 12 & $\begin{array}{l}\text { After teaching a lesson developed by the team, I find the observers' } \\
\text { comments and the reflection/ revision process helpful }\end{array}$ \\
\hline & 13 & $\begin{array}{l}\text { I feel more comfortable teaching lessons with observers in the classroom } \\
\text { as a result of the Lesson Study Process }\end{array}$ \\
\hline & 14 & $\begin{array}{l}\text { The Lesson Study Process makes me feel more comfortable in teaching } \\
\text { EFL }\end{array}$ \\
\hline & 15 & $\begin{array}{l}\text { Participating in a Lesson Study process was a valuable professional } \\
\text { development activity }\end{array}$ \\
\hline & 16 & I plan to continue using Lesson Study in the future \\
\hline
\end{tabular}

where one of them chose disagree and the rest of them chose strongly agree. The result of the data above indicated that the lecturers followed the steps and could get a positive use of each step starting from planning the research lesson, solving the problems related to the research lesson, observing the teaching practice by focusing on student learning and doing reflection. Those steps were done within collegial work among the lecturers where they had systematic opportunities to learn from colleagues. This result matches with the relevant references stating that colleagues can assist each other learn from both instructional material and from practice (Grandau, 2005; Lewis, Perry \& Hurd, 2009; Ticha \& Hospesova, 2006). Additionally, colleagues provide a 
need to make one's thinking visible and they offer ideas, questions, and challenges (Linn, Eylon, \& Davis, 2004).

\section{The effectiveness of lesson study in improving pedagogical skill in teaching EFL}

Data dealing with the lecturers' perception of effectiveness of Lesson Study in improving pedagogical skill is drawn in the Figure 2, as follows:

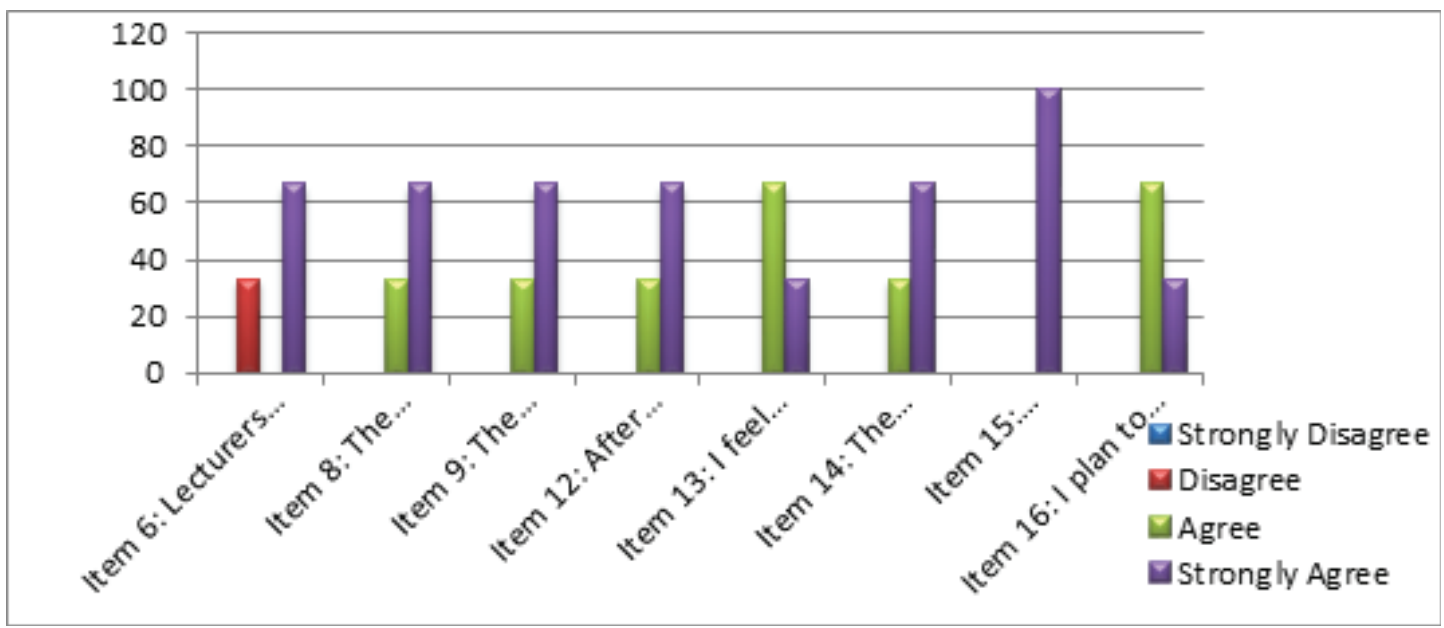

Figure 3: The lecturers' answer on the effectiveness of Lesson Study in improving pedagogical skill in teaching EFL.

From the total seven items out of eight items delivered, the data showed that all lecturers responded positively to the effective use of Lesson Study in improving their pedagogical skill. This finding reflected to the answers of the lecturers who chose agree and strongly agree in the item 8, item 9, item 12, item 13, item 14, and item 16 as well as they chose strongly agree in item 15. This total percentage of positive response outweighs the number of participants who gave negative response. Based on the figure above, it was only one lecturer who gave a negative response by choosing 'disagree' in the item 6.

In overall, the data percentage above implied that the lecturers' pedagogical content knowledge has increased as a result of participating in the Lesson Study process. This statement supported by the lecturers' positive response in the development of research lesson has allowed them to increase their knowledge of teaching content, that development of research lesson has allowed them to understand the way students think better and/or the difficulties of their teaching content, and that they feel comfortable with their teaching. The participants also agreed that Lesson Study was a valuable 
professional development activity and they plan to continue using Lesson Study in the future.

This finding is in line with what Ektefaei (2006) suggested where the reason may be from the idea that teachers found a significant different between lesson study and other traditional professional development. Additionally, they also noticed the strong and weak points of their teaching, since Lesson Study provided teachers to talk about ideas they never thought through their experience in a collaborative teaching practice (Moghaddam et al, 2015).

\subsection{RQ \#2: What are the problems that lecturers encountered dur- ing Lesson Study process?}

In order to answer the second research question, the data was gained from three openended questions. Table 2 below shows the answer of each lecturer.

TABLE 2: Data of open-ended questions.

\begin{tabular}{|c|c|c|c|}
\hline & \multicolumn{3}{|c|}{ Open-ended Questions \& Answer } \\
\hline & $\begin{array}{l}\text { Using the Lesson Study process, is } \\
\text { your content knowledge and } \\
\text { pedagogical skill changing? If yes, } \\
\text { how is it changing? }\end{array}$ & $\begin{array}{l}\text { Are there any } \\
\text { issues/problems that you } \\
\text { foresee with the Lesson } \\
\text { Study Process as you try in } \\
\text { your university? }\end{array}$ & $\begin{array}{l}\text { What are some ideas for } \\
\text { overcoming some of the } \\
\text { issues/ problems? }\end{array}$ \\
\hline L1 & We plan and observe better & $\begin{array}{l}\text { That was difficult to } \\
\text { determine what materials } \\
\text { to present with which } \\
\text { method }\end{array}$ & $\begin{array}{l}\text { We still try to use the } \\
\text { materials given in the } \\
\text { syllabus and apply some } \\
\text { methods simultaneously }\end{array}$ \\
\hline L2 & $\begin{array}{l}\text { They improve. I did more readings } \\
\text { on journals and teaching methods. } \\
\text { The other members also share new } \\
\text { knowledge and teaching tips. The } \\
\text { observation on students gave me } \\
\text { new insights about how they learn } \\
\text { the material. }\end{array}$ & $\begin{array}{l}\text { Time management. We } \\
\text { hardly found convenient } \\
\text { time for everyone to have } \\
\text { discussion. }\end{array}$ & $\begin{array}{l}\text { There should be } \\
\text { commitment among the } \\
\text { members. }\end{array}$ \\
\hline L3 & $\begin{array}{l}\text { Yes, it is. I get more feedback from } \\
\text { the observers }\end{array}$ & Time allotment & $\begin{array}{l}\text { Implement to another } \\
\text { subject }\end{array}$ \\
\hline
\end{tabular}

From the table above, it indicated that all lecturers agreed their content knowledge and pedagogical skill changing after participating in the Lesson Study program. Mostly the improvements were gained through the collegiality work among lecturers, such as from planning, observing and reflecting activities. Besides, L2 also added that she also did some readings on journals and teaching methods.

Additionally, related to the problems encountered during the Lesson Study program, $\mathrm{L} 2$ and $\mathrm{L} 3$ stated that time management as the main problem. This happened probably 
because all the members usually have courses schedule that difficult to adjust each other. As a result, the collaboration and collegiality among lecturers could not be maximized during the program, since they have limited time to do discussion. In line with this finding, some other related studies also found the issue of time management as the main problems during Lesson Study program (Coskun, 2017; Lenski, Caskey \& Anfara, 2009; Utami \& Nafi'ah, 2015). In overcoming the problem above, L2 suggested that commitment among the members was important to support the program. Besides the problem in time management, according to L1, another one is related to the planning stage where the focus was on choosing materials being taught and the teaching method used in teaching practice. Responding to this problem, L1 suggested focusing on the syllabus and applying some method frequently in order to suit students learning.

\section{Conclusion}

In summary, the findings of this study suggest that performing Lesson Study procedures in classrooms helps EFL lecturers to promote their teaching and helps them get the characteristics of effective professional development in their work. Based on the data delivered in the previous section above, it found out that the lecturers had a positive perspective on using Lesson Study in improving pedagogical content knowledge in teaching EFL. Even though in the implementation, the lecturers face the problems related to the time management in terms of conducting the discussion with the members of the Lesson Study. Dealing with this problem, it is suggested that the lecturers should have more desire and enthusiasm in participating with the program.

\section{References}

[1] Bogdan, R. \& Biklen, S. K. (2006). Qualitative Research for Education: An Introduction to Theories and Methods. USA Pearson Education, Inc.

[2] Coskun, A. (2017). The Application of Lesson Study in Teaching English as a Foreign Language, Inonu University Journal of the Faculty of Education, 18(1), 151-162. DOI: 10.17679/inuefd.297845

[3] Creswell, J. W. (2008). Educational Research: Planning, Conducting, and Evaluating Quantitative and Qualitative Research. Third Edition. New Jersey: Pearson Education International.

[4] Ektefaei N. H. (2006). The impact of lesson study on mathematics teachers. Unpublished. MA thesis. Shahid Bahonar University. Kerman, Iran. 
[5] Grandau, L. (2005). Learning from self-study: Gaining knowledge about how fourth graders move from relational description to algebraic generalization. Harvard Educational Review, 75(2), 202-221.

[6] Kenellopuolou, E. M., \& Darra, M. (2018). The Planning of Teaching in the Context of Lesson Study: Research finding. International Education Studies, 11(2), 67-82

[7] Lee, S. M., \& Oyao, S. G. (2013). Establishing Learning Communities among Science Teachers through Lesson Study. Journal of Science and Mathematic Education in South Eas Asia, 36(1), 1-22. Retrieved August 11, 2015, from http://www.recsam.edu.my/R\{\%\}26D_Journals/YEAR2013/June2013vol1/ abstract/abstracts\{\%\}20lee\{\%\}20page\{\%\}201\{\%\}20to\{\%\}2022.pdf

[8] Lenski, S. J., Caskey, M. M., \& Anfara Jr, V. A. (2009). Using the lesson study approach to plan for student learning. Middle School Journal, 40(3), 50-57.

[9] Lewis, C. C. (2002). Lesson study: A handbook of teacher-led instructional change. Philadelphia, PA: Research for Better Schools.

[10] Lewis, C.C. \& Hurd, J. 2011. Lesson Study Step by Step: How Teacher Learning Communities Improve Instruction. United Stated of America: Heinemman.

[11] Lewis, C., Perry, R., \& Hurd, J. (2009). Improving mathematics instruction through lesson study: A theoretical model and North American case. Journal of Mathematics Teacher Education, 12(4), 285-304. DOI: 10.1007/s10857-009-9102-7

[12] Lewis, C., Perry, R., Hurd, J., \& O'Connell, M. P. (2006). Lesson study comes of age in North America. Phi Delta Kappan, December 2006, 273-281.

[13] Linn, M., Eylon, B., \& Davis, E. (2004). The knowledge integration perspective on learning. In M. Linn, E. Davis, \& P. Bell (Eds.), Internet Environments for Science Education, 29-46.

[14] Malik, R. S., \& Hamied, F. A. (2016). Research Method. Bandung: UPI PRESS.

[15] Moghaddam, A. R., Sarkar A. M. R., Kuno, H. (2015). A collaborative inquiry to promote pedagogical knowledge of mathematics in practice. Issues in Educational Research, 25(2), 170.

[16] Newmann, F. M., King, M. B., \& Youngs, P. (2000). Professional development that addresses school capacity: Lessons from urban elementary schools. American Journal of Education, 108(4), 259-299.

[17] Rock, T. C., \& Wilson, C. (2005). Improving Teaching throuh Lesson Study. Teacher Education Quarterly, 77-92. Retrieved August 11, 2015, from http://www.teqjournal. org/backvols/2005/32_1/rock\{\%\}26wilson.pdf

[18] Sato, M. (2014). Retrospeck and Prospect of School as Learning Community in Asia. First International Conference of School as Learning Community (pp. 1-46). Tokyo: 
The International Network for School as Learning Community. Retrieved August 11, 2015, from http://school-Ic.com/wp-content/uploads/Opening-Remark.pdf

[19] Seyf, A. (1996). Educational psychology. Tehran. Agah Press.

[20] Stepanek, J., et.al. (2007). Leading Lesson Study: A Practical Guide for Teachers and Facilitators. California: Corwin Press.

[21] Stigler, J. W., \& Hiebert, J. (1999). The teaching gap: Best ideas from the world's teachers for improving education in the classroom. New York, NY: Summit Books.

[22] Sumardi, Subadi, T., \& Sutarni. (2015). Model Pembinaan Doses Berbasis Program Perluasan Lesson Study untuk Penguatan Proses Pembelajaran di LPTK FKIP Universitas Muhammadiyah Surakarta. University Research Colloquium (pp. 128135). Surakarta: Lembaga Penelitian dan Pengabdian Masyarakat Universitas Muhammadiyah Surakarta.

[23] Ticha, M., \& Hospesova, A. (2006). Qualified pedagogical reflection as a way to improve mathematics education. Journal of Mathematics Teacher Education, 9(2),129-156.

[24] Tyoso, B. W. (2007). Budaya Kolegialitas Akademik sebagai Pendukung Kehidupan Akademik yang Kondusif. Yogyakarta: UGM.

[25] Utami, I. W. P., \& Nafi'ah, U. (2015). Developing lecturer collegiality through lesson study. Presented in 6th International Conference on Lesson Study: Undiksha, Singaraja. Retrieved from https://www.academia.edu/16857609/ DEVELOPING_LECTURER_COLLEGIALITY_THROUGH_LESSON_STUDY

[26] Wright Jr, T. D. (2009). Investigating teachers' perspectives on the impact of the lesson study process on their mathematical content knowledge, pedagogical knowledge, and the potential for student achievement. Dissertations and Theses: University of New Orleans Theses and Dissertations 